\title{
Mosquitocidal and water purification properties of Ocimum sanctum and Phyllanthus emblica
}

\author{
K. Murugan, ${ }^{1}$ P. Madhiyazhagan, ${ }^{1}$ A. Nareshkumar, ${ }^{1}$ T. Nataraj, ${ }^{1}$ D. Dinesh, ${ }^{1}$ J.S. Hwang, ${ }^{2}$ \\ M. Nicoletti ${ }^{3}$ \\ ${ }^{1}$ Division of Entomology, Department of Zoology, School of Life Sciences, Bharathiar University, \\ Coimbatore, India; ${ }^{2}$ Institute of Marine Biology, National Taiwan Ocean University, Keelung, \\ Taiwan; ${ }^{3}$ Department of Environmental Biology, Università “La Sapienza”, Rome, Italy
}

\begin{abstract}
Ocimum sanctum was tested for its larvicidal and water sedimentation properties; the fruit ethanol and methanol extracts of Phyllanthus emblica were tested for phytochemical, larvicidal, oviposition-deterrent and ovicidal activities. Results emphasized that plant extracts have high toxicity against the egg and larvae of the malarial vector Anopheles stephensi and also have water sedimentation properties. $\mathrm{LC}_{50}$ of Phyllanthus emblica against Anopheles stephensi larvae ranged from 33.08 ppm to $81.26 \mathrm{ppm}$ and from 23.44 to $54.19 \mathrm{ppm}$ for ethanol and methanol extracts, respectively. Phyllanthus emblica also showed excellent ovipositional deterrent and ovicidal activities. The oviposition activity index value of ethanol and methanol extracts of Phyllanthus emblica at $500 \mathrm{ppm}$ were -0.80 and -0.92 , respectively. Ocimum sanctum includes both insecticidal secondary compounds, amino acids (glycine, lysine), vitamin $\mathrm{C}$ and other substances, that make treated water suitable for human consumption. Water quality parameters such as color, turbidity and $\mathrm{pH}$ were analyzed in the water samples (pre-treatment and post-treatment of plant extracts) taken
\end{abstract}

Correspondence: Kadarkarai Murugan, Division of Entomology, Department of Zoology, School of Life Sciences, Bharathiar University, Coimbatore, India. E-mail: kmvvkg@gmail.com

Key words: Anopheles stephensi, Ocimum sanctum, Phyllanthus emblica, ovipositional deterrent, ovicidal, mosquitocidal, water purification.

Acknowledgements: the authors thank the Council of Scientific and Industrial Research CSIR (Sanction letter No. 37(1386) EMRII dated 02-062010), Government of India, New Delhi, for providing financial assistance.

Received for publication: 20 August 2012.

Revision received: 28 November 2012.

Accepted for publication: 28 November 2012.

(ㄷ) Copyright K. Murugan et al., 2012

Licensee PAGEPress, Italy

Journal of Entomological and Acarological Research 2012; 44:e17

doi:10.4081/jear.2012.e17

This article is distributed under the terms of the Creative Commons Attribution Noncommercial License (by-nc 3.0) which permits any noncommercial use, distribution, and reproduction in any medium, provided the original author(s) and source are credited. from the breeding sites of mosquitoes. Hence, the plant product can be used as both mosquitocidal and water purifier.

\section{Introduction}

Mosquitoes are the most single group of insects in terms of public health significance and transmitting dreaded diseases like malaria, filariasis and dengue, etc. There are approximately 460 recognized species. While over 100 can transmit human malaria, only 30-40 commonly transmit parasites of the genus Plasmodium that causes malaria which affects humans in endemic areas. The known vectors of Anopheles species, which are common in India, include A. stephensi, $A$. culicifacies, A. fluviattis, A. minimmus, A. sudanicus and A. philippinensis. Anopheles stephensi Liston, 1901 (Diptera: Culicidae) is the most common human-biting malaria vector in India and many West Asian countries, and is likely responsible for $40-50 \%$ of the annual malarial incidence (Curtis, 1994).

The problems of high cost, environmental risks and development of resistance in many vector mosquito species to several synthetic insecticides have revived interest in exploiting the pest control potential of plants (Grainage \& Ahamed, 1988). Conventional water treatment relies on the addition of chemicals such as alum (aluminum sulfate) as coagulants and the addition of chlorine as a bactericide. The availability of these chemicals, which depends on foreign exchange, is unreliable and unpredictable. Because of economic and political constraints, the universal provision of piped water is not currently feasible, leaving millions of people without access to safe drinking water (WHO, 2005). This led us to look for plants with water purification properties.

Ocimum sanctum (holi basil), also called Tulsi in India, is ubiquitous in Indian tradition. Tulsi is described as a sacred medicinal plant in ancient literature (Kirtikar \& Basu, 1975). It has been used to treat malarial fevers, ringworms, and other cutaneous afflictions (Butani, 1982). A variety of biologically active compounds have been isolated from the leaves, including ursolic acid, apigenin and luteolin. Some other main chemical constituents of Tulsi are Oleanolic acid, Rosmarinic acid, Eugenol, Carvacrol, Linalool, and $\beta$-caryophyllene (Merrily \& Winston, 2007). This paper, therefore, describes the mosquitocidal and water sedimentation properties of Ocimum sanctum against malarial vector, Anopheles stephensi.

The plant genus Phyllanthus L. (Euphorbiaceae) is widely distributed in most tropical and subtropical countries. It is a very large genus consisting of approximately 550 to 750 species and is subdivided into ten or eleven subgenera. Phyllanthus emblica $L$. has been used for the 
anti-inflammatory and anti-pyretic treatments by the rural population and for the treatment of several disorders such as the Scurvy, Cancer and Heart diseases. The important constituent of plant leaves has antineutrophilic activity and anti-platelet properties in vitro. The extracts also have several pharmacological properties, such as anti-viral (HIV, AIDS, herpes virus, cytomegalovirus) antimutagenic, antiallergic, antibacterial activities (Khopde et al., 2000). Phyllanthus emblica L. contains a different class of secondary metabolites (Calixto et al., 1998).

The present study aimed to evaluate the effect of mosquitocidal and water sedimentation properties of Ocimum sanctum on the malaria vector Anopheles stephensi and screen phytochemicals from Phyllanthus emblica $L$. for larvicidal, pupicidal, oviposition deterrent and ovicidal effect against the same malaria vector.

\section{Materials and methods}

\section{Colonization, mosquito rearing and maintenance}

The eggs of Anopheles stephensi Liston, 1911 were collected from various water sources (e.g., overhead tanks) in Coimbatore district, Tamil Nadu, India. The eggs were brought to the laboratory and were transferred to $18 \times 13 \times 4 \mathrm{~cm}$ size enamel trays containing $500 \mathrm{~mL}$ of water until they hatched. After hatching, the larvae were provided with dog biscuits and yeast at a $3: 1$ ratio and maintained at $27+2^{\circ} \mathrm{C}, 75-85 \% \mathrm{RH}$, under $14 \mathrm{~h}$ light (L): $10 \mathrm{~h}$ dark (D) photoperiod cycles. Pupae were collected and transferred to plastic jars $(12 \times 12 \mathrm{~cm})$ containing $500 \mathrm{~mL}$ of water, which were placed in $90 \times 90 \times 90 \mathrm{~cm}$ screened mosquito cage for adult emergence. The freshly emerged adults were maintained at $27 \pm 2{ }^{\circ} \mathrm{C}, 75-85 \% \mathrm{RH}$, under $14 \mathrm{~h} \mathrm{L:} 10 \mathrm{~h}$ D photoperiod cycles. The adults were provided a $20 \%$ sugar solution ad libitum, and provided with rabbits (each exposed on the dorsal side) for 30 min two times per week (Hardstone et al., 2009). The males were provided with a 10\% glucose solution on cotton wicks that was changed daily. Blood-fed females were provided filter paper-lined cups containing water for oviposition.

\section{Collection of plant material and preparation of extracts}

The leaves of Ocimum sanctum and Phyllanthus emblica fruits were collected from in and around Bharathiar University Campus, Coimbatore, Tamil Nadu, India. A total of $250 \mathrm{~g}$ of fresh, mature leaves was rinsed with distilled water and dried in a shade. The dried leaves were put in a Soxhlet apparatus (Borosil Glass Workers Ltd., Worli, Mumbai, India), and extracts were prepared using 100\% ethanol (Loba Chemie Pvt. Ltd., Mumbai, India; $99 \%$ purity) for $72 \mathrm{~h}$ at $30-40^{\circ} \mathrm{C}$. Dried residues were obtained from $100 \mathrm{~g}$ of extract evaporated to dryness in a rotary vacuum evaporator. Two grams of the residues were dissolved in $100 \mathrm{~mL}$ of ethanol ( $2 \%$ stock solution), from which the following concentrations were prepared: $0.5 \%, 0.1 \%, 2.0 \%, 4.0 \%$, and $8.0 \%$, using distilled water.

Amla fruits were cut into small pieces and ground into a uniform powder using a blender. The methanolic extract of amla was prepared by soaking $100 \mathrm{~g}$ of dried powdered samples in $250 \mathrm{~mL}$ of methanol for $12 \mathrm{~h}$. The extracts were filtered by using Whatman $\mathrm{n} .1$ filter paper. The filtrate was used for phytochemical screening. The preliminary qualitative phytochemical studies were performed for testing the different chemical groups present in fruit methanol extract of Phyllanthus emblica (Trease et al., 1978; Kokate et al., 1990).

\section{Laboratory plant extract toxicity tests}

F1-F2 larvae/pupae from the wild adult collection were used to evaluate larvicidal activity. Twenty-five larvae (in stages I to IV and pupae) were placed into a 500-mL glass beaker containing $249 \mathrm{~mL}$ of dechlori- nated water and $1 \mathrm{~mL}$ of desired concentrations of plant extract. Test larvae and pupae were provided with food as previously described. At each tested concentration, 2-5 trials of 3 replicates were conducted concurrently. Control groups of larvae exposed to ethanol served as control. Mortality was corrected using Abbott's formula (Abbott, 1925).

$\begin{aligned} & \text { Corrected } \\ & \text { mortality }\end{aligned}=\frac{\text { Observed mortality in treatment }- \text { Observed mortality in control }}{100-\text { Control mortality }} \times 100$

$$
\text { Percentage mortality }=\frac{\text { Number of dead larvae } / \text { pupae }}{\text { Number of larvae/pupae introduced }} \times 100
$$

\section{Ovicidal activity assay}

For ovicidal activity, the freshly laid eggs were collected by providing ovitraps in mosquito cages. Ovitraps were kept in the cages two days after the female mosquitoes had been given a blood meal. The eggs were laid on the filter paper lining provided in the ovitrap. After scoring, 100 gravids were placed in a screen cage where ten oviposition cups were introduced for oviposition $30 \mathrm{~min}$ before the start of the dusk period. Of these ten cups, eight were each filled with test solution of 150, 200, 250, $300,350,400,450,500 \mathrm{ppm}$, and one was filled with $100 \mathrm{~mL}$ of respective solvent containing water and Polysorbate 80 that served as a control. A minimum of 100 eggs were used for each treatment, and the experiment was replicated 5 times. After treatment, the eggs were sieved through muslin cloth, thoroughly rinsed with tap water, and left in plastic cubs filled with dechlorinated water for hatching assessment after counting the eggs under the microscope (Su \& Mulla, 1998). The percent egg mortality was calculated on the basis of non-hatchability of eggs with unopened opercula (Chenniappan \& Kadarkarai, 2008). The hatching rate of eggs was assessed after $98 \mathrm{~h}$ post-treatment according to the method of Rajkumar and Jebanesan (2009).

\section{Oviposition deterrence activity}

To study the ovipositional deterrence effect and the number of eggs deposited in the presence of extracts with different solvents of experimental plants, a multiple concentration test was carried out. For bioassay test, 20 males and 20 females were separated in the pupal stage (by size of the pupae) and were introduced into screen cages $(45 \times 45 \times 40$ $\mathrm{cm}$ ) in a room at $27 \pm 2^{\circ} \mathrm{C}$ and $75-85 \%$ relative humidity (RH) with a photoperiod of 14:10 $\mathrm{h}$ light and dark cycles. The pupae were allowed to emerge to adults in the test cages. Adults were provided continuously with $10 \%$ sucrose solution in a plastic cup with a cotton wick. They were blood fed (from pigeon) on Day 5 after emergence. In the multiple concentration test, five cups, each containing $100 \mathrm{~mL}$ distilled water with a 9 -cm piece of white filter paper for oviposition, as well as solvent extracts at concentrations of 100,200, 300, 400 and $500 \mathrm{ppm}$, were placed in each cage. A sixth cup without extract served as a control. The positions of the plastic cups were alternated between the different replicates so as to nullify any effect of position on oviposition. Five replicates for each concentration were run with cages placed side by side for each bioassay. After $24 \mathrm{~h}$, the number of eggs laid in the treated and control cups were counted under a stereomicroscope. The percent effective repellency for each concentration was calculated using the following formula:

$$
E R(\%)=\frac{\mathrm{NC}-\mathrm{NT}}{N C} \times 100
$$

where ER is effective repellency, $\mathrm{NC}$ is number of eggs in control, and NT is number of eggs in treatment (Rajkumar \& Jebanesan, 2009). The oviposition experiments were expressed as mean number of eggs and oviposition activity index, which was calculated using the following formula: 
insoluble material with a fine-mesh screen or muslin cloth, the coagu-

$$
O A I=\frac{\mathrm{NT}-\mathrm{NS}}{\mathrm{NT}+\mathrm{NS}}
$$

where NT is total number of eggs in the test solution and NS is total number of eggs in the control solution. Oviposition active index of +0.3 and above are considered as attractants while those with -0.3 and below are considered as repellents (Kramer \& Mulla, 1979). Positive values indicate that more eggs were deposited in the test cups than in the control cups and that the test solutions were attractive. Conversely, negative values indicate that more eggs were deposited in the control cups than in the test cups and that the test solutions were a deterrent.

\section{Field trials of plant extract larval toxicity}

Plant extracts formulations (51 $\left.\mathrm{g}^{*} \mathrm{l}-1\right)$ were applied to the water surface with a knapsack sprayer (Ignition Products Ltd., India, 2008). Pretreatment and post-treatment at 24,48 and $72 \mathrm{~h}$ was conducted using a larval dipper. Larvicidal efficacy was carried out against late third and early fourth-instar larvae. Larvae were identified and counted to determine the relative species composition of each test site. Six trials were conducted for each test site (standing water bodies) with similar weather conditions $\left(27^{\circ} \mathrm{C} ; 79 \% \mathrm{RH}\right)$. The required quantity of plant extract was determined by calculating the total surface area and volume $\left(0.25 \mathrm{~m}^{2}\right.$ and $\left.250 \mathrm{~L}\right)$. The required concentration was prepared using 10 times the observed laboratory $\mathrm{LC}_{50}$ values (Murugan et al., 2003). Percentage reduction of the larval density was calculated using the formula:

$$
\text { Percentage reduction }=\frac{\mathrm{C}-\mathrm{T}}{\mathrm{C}} \times 100
$$

where $\mathrm{C}$ is the total number of mosquitoes in control and $\mathrm{T}$ is the total number of mosquitoes in treatment.

\section{Water quality parameters}

Water quality parameters such as $\mathrm{pH}$, color and turbidity were investigated using the methods of Clescerl et al. (2005). To prepare the coagulants and treatment (Schwarz, 2000), leaves of Ocimum sanctum were shade-dried, powdered using an electric blender, and mixed with a small amount of clean water to form a paste. The paste was diluted to the required strength based on raw water turbidity. Total suspended solids in raw water separated as over 50 , between 50 and 150 , and over $150 \mathrm{mg}^{*} \mathrm{l}-1$, and the final concentration used for treatment was 50,30 100 and over $150 \mathrm{mg}^{*} \mathrm{l}-1$, respectively (Schwarz, 2000). After filtering lant was added and stirred fast for $30 \mathrm{~s}$. The treated water was then covered for $1 \mathrm{~h}$ without disturbance.

\section{Statistical analysis}

The SPSS (Version 9.0) software package was used to analyze data obtained from the bioassay. Lethal concentrations (LC), $\mathrm{LC}_{50}$ and $\mathrm{LC}_{90}$, Duncan Multiple Range Test) and $\chi^{2}$ tests were used.

\section{Results}

Ocimum sanctum leaf extract was used to test water purification properties including water color, total suspended solids and $\mathrm{pH}$, and was effective in sedimentation and purification. Before treatment, water color was $31 \mathrm{HU}$ while after this was $12 \mathrm{HU}$. Total suspended solids before treatment was $40.0 \mathrm{mg}^{*} \mathrm{l}-1$ and this was reduced 30.0 mg*l-1, after. Similarly, pH level was 8 before treatment and 6.8 after.

Significant mortality was evident after the treatment of Ocimum sanctum leaf extract (OSLE) at different concentrations against $A$. stephensi in laboratory (Table 1). After the treatment of OSLE at different concentration levels (0.5-8\%), 38\% mortality was noted at I instar larvae by the treatment of OSLE at $0.5 \%$, whereas this increased to $90 \%$ at $8 \%$ of OSLE treatment. Mortality increased with increasing concentration. Lethal concentrations $\left(\mathrm{LC}_{50}\right.$ and $\left.\mathrm{LC}_{90}\right)$ were also calculated. The $\mathrm{LC}_{50}$ and $\mathrm{LC}_{90}$ values are represented as follows: $\mathrm{LC}_{50}$ value of I instar was $1.52 \%$, II instar was $2.22 \%$, III instar was $3.11 \%$, IV instar was $5.13 \%$ and pupae was $6.45 \%$. $\mathrm{LC}_{90}$ value of I instar was $7.39 \%$, II instar was $8.68 \%$, III instar was $10.07 \%$, IV instar was $14.11 \%$ and pupae was $15.24 \%$, respectively.

An. stephensi larvae were collected exclusively in overhead water tanks and mean larval count was calculated. Breeding sites treated with 0 . sanctum extracts, showed a reduction in An. stephensi larvae. The field experiment was carried out at drinking water tanks $(0.5 \times 0.5 \times 1.0)$ with Anopheles stephensi larvae and the percentage reduction/mortality was $82.5 \%, 87.9 \%$ and $92.4 \%$ after the $24 \mathrm{~h}, 48 \mathrm{~h}$ and $72 \mathrm{~h}$, respectively (Table 2).

Table 3 shows qualitative analyses of the fruit extract of Phyllanthus emblica, emphasizing the presence of proteins, tannins and terpenoids. Steroids were absent in Phyllanthus emblica.

The larvicidal and pupicidal activities of the ethanol extract of Phyllanthus emblica against Anopheles stephensi larvae under laborato-

\begin{tabular}{|c|c|c|c|c|c|c|c|c|c|}
\hline $\begin{array}{l}\text { Larval } \\
\text { instars } \\
\text { and Pupa }\end{array}$ & 0.5 & $\begin{array}{l}\text { Larv } \\
\text { centratic } \\
1.0\end{array}$ & $\begin{array}{l}\text { mortality } \\
\text { of Ocimu } \\
2.0\end{array}$ & $\begin{array}{l}\text { 6) } \pm \mathrm{SD} \\
\text { anctum } \\
4.0\end{array}$ & 8.0 & $\begin{array}{c}\mathrm{LC}_{50} \\
\left(\mathrm{LC}_{90}\right)\end{array}$ & $\begin{array}{c}95 \% \text { Con } \\
\text { LCL } \\
\text { LC }_{50}\left(\mathrm{LC}_{90}\right)\end{array}$ & $\begin{array}{l}\text { nce limit } \\
\text { UCL } \\
\text { LC }_{50}\left(\mathrm{LC}_{90}\right)\end{array}$ & $\begin{array}{c}\text { Chi-square } \\
\text { value }\end{array}$ \\
\hline I & $38 \pm 0.6^{\mathrm{a}}$ & $43 \pm 0.3^{\mathrm{ab}}$ & $58 \pm 1.2^{\mathrm{b}}$ & $75 \pm 0.5^{c}$ & $90 \pm 0.8^{d}$ & $\begin{array}{c}1.52067 \\
(7.38616)\end{array}$ & $\begin{array}{c}0.85569 \\
(2.07067)\end{array}$ & $\begin{array}{c}6.34024 \\
(8.99671)\end{array}$ & $2.830^{*}$ \\
\hline II & $32 \pm 0.9^{a}$ & $41 \pm 0.5^{b}$ & $50 \pm 1.0^{c}$ & $69 \pm 0.7^{d}$ & $85 \pm 1.1^{\mathrm{e}}$ & $\begin{array}{c}2.21933 \\
(8.68104)\end{array}$ & $\begin{array}{c}1.57467 \\
(2.80353)\end{array}$ & $\begin{array}{c}7.42155 \\
(10.65323)\end{array}$ & $2.769^{*}$ \\
\hline III & $26 \pm 1.0^{a}$ & $35 \pm 1.2^{b}$ & $46 \pm 1.4^{c}$ & $61 \pm 0.8^{d}$ & $79 \pm 1.5^{\mathrm{e}}$ & $\begin{array}{c}3.10581 \\
(10.06631)\end{array}$ & $\begin{array}{c}2.47306 \\
(3.76193)\end{array}$ & $\begin{array}{c}8.56234 \\
12.46361\end{array}$ & $3.384^{*}$ \\
\hline IV & $19 \pm 1.5^{\mathrm{a}}$ & $25 \pm 0.8^{\mathrm{ab}}$ & $39 \pm 0.6^{b}$ & $52 \pm 1.2^{c}$ & $61 \pm 0.4^{\mathrm{d}}$ & $\begin{array}{c}5.12732 \\
(14.11467)\end{array}$ & $\begin{array}{c}2.94904 \\
(13.82370)\end{array}$ & $\begin{array}{c}9.02274 \\
(56.49114)\end{array}$ & $8.278^{*}$ \\
\hline Pupa & $10 \pm 0.5^{\mathrm{a}}$ & $21 \pm 1.0^{b}$ & $32 \pm 1.2^{c}$ & $46 \pm 0.8^{d}$ & $53 \pm 0.6^{\mathrm{e}}$ & $\begin{array}{c}6.44729 \\
(15.23744)\end{array}$ & $\begin{array}{c}3.67191 \\
570.79738\end{array}$ & $\begin{array}{c}9.00805 \\
(2199.74679)\end{array}$ & $13.287^{*}$ \\
\hline
\end{tabular}

Table 1. Larvicidal activity of Ocimum sanctum against malaria vector, Anopheles stephensi.

Within a column means followed by the same letter(s) are not significantly different at $5 \%$ level by Duncan Multiple Range Test; ${ }^{*}$ Significant at $\mathrm{P}<0.001$ (heterogeneity factor used in calculation of confidence limits). $\mathrm{SD}$, standard deviation; $\mathrm{LC}_{50}$, $\mathrm{LC}_{90}$, lethal concentration; $\mathrm{LCL}$, lower confidence limits; UCL, upper confidence limits. 
ry conditions are given in Table 4 . Percentage mortality was $43 \%$ at 20 ppm concentration and increased to $82 \%$ at $100 \mathrm{ppm}$ concentration against the first instar larvae. Median lethal concentrations (33.08, $48.85,68.28,81.26$ and $86.24 \mathrm{ppm}$ ) for larvae and pupae were low and significant.

Table 5 shows larvicidal and pupicidal activities of methanol extract of Phyllanthus emblica against the malarial vector, Anopheles stephen$s i$. Among the four larval stages, I Instar larvae were more susceptible than the other instars. The fruit extracts also showed considerable pupal mortality. The lowest mortality observed was $20 \%$ at $20 \mathrm{ppm}$ against pupae and the highest was $98 \%$ at 100 ppm against the I instar larvae. $\mathrm{LC}_{50}(23.44,33.10,42.13,54.19$ and $64.28 \mathrm{ppm}$ for four instar larvae and pupae, respectively) observed for larvae and pupae were very low when compared to the ethanol extract.

In the oviposition deterrent assay, gravid Anopheles stephensi preferred to lay eggs in the distilled water control cups than in the cups treated with solvent extracts of Phyllanthus emblica (Table 6). There was also a marked difference in the number of eggs laid. Observed results showed that the $500 \mathrm{ppm}$ treated cups received a mean number of $49 \pm 1.15$ and $19 \pm 1.53$ eggs per cup in fruit ethanol and methanol extracts of Phyllanthus emblica treatment while the control cups received a mean number of $456 \pm 1.50$ and $470 \pm 1.30$ eggs per cup. The present results indicated that the oviposition deterrence was concentration dependent, as $500 \mathrm{ppm}$ of ethanol and methanol fruit extracts of

Table 2. Effect of Ocimum sanctum treatments of drinkng water tanks malarial vector, Anopheles stephensi.

\begin{tabular}{lcccc} 
Site no. & \multicolumn{3}{c}{$\begin{array}{l}\text { Larval density (\%) } \\
\text { Before treatment }\end{array}$} & \multicolumn{3}{c}{ After treatment } \\
& & $24 \mathrm{~h}$ & $\mathbf{4 8} \mathrm{h}$ & $\mathbf{7 2} \mathrm{h}$ \\
\hline 1 & 79 & 19 & 15 & 11 \\
2 & 71 & 14 & 12 & 8 \\
\hline 3 & 65 & 10 & 8 & 5 \\
4 & 57 & 7 & 6 & 3 \\
\hline 5 & 47 & 7 & 2 & 0 \\
6 & 39 & 4 & 0 & 0 \\
\hline Total & 358 & 61 & 43 & 27 \\
Average & 59.6 & 10.1 & 7.16 & 4.50 \\
\% Reduction & - & 82.50 & 87.9 & 92.4 \\
\hline
\end{tabular}

Place: Vadavalli;

-Habitat: drinking water;

Size: $0.5 \times 0.5 \times 1.0$;

-Depth: $1 \mathrm{~cm}$;

-Species: Anopheles stephensi;

-Stage: larvae stage;

-Calculation: $2.5 \times 1.5 \mathrm{~m} ; 3.10 \times 1=31.00$.

Table 3. Phytochemical constituents present in Phyllanthus emblica.

\begin{tabular}{lcc} 
Phyto-constituents & Ethanol extract & Methanol extract \\
Flavonoidds & + & + \\
Tannins & + & + \\
\hline Carbohydrates & + & + \\
Alkaloids & + & + \\
\hline Proteins & + & + \\
Steroids & - & - \\
\hline Terpenoids & + & + \\
\hline
\end{tabular}

experimental plant exhibits strong deterrent effect when compared with $100 \mathrm{ppm}$ against oviposition. The solvent leaf extracts strongly deterred oviposition by gravid Anopheles stephensi, with a significantly lower proportion of eggs being laid on ovitraps containing extracts in comparison with control solutions $(\mathrm{P}<0.05)$. The maximum percentage of effective repellency against oviposition was $96.93 \%$, reported in 500 ppm followed by $95.95,94.13,87.01,78.18$ and $67.50 \%$ at 500, 400, 300, 200 and 100 ppm methanol extracts of Phyllanthus emblica, respectively. The percentages of egg hatchability of Anopheles stephensi with the fruit ethanol and methanol extracts of Phyllanthus emblica are presented in Table 7. The ethanol and methanol extracts of Phyllanthus emblica exerted $100 \%$ mortality (no hatchability) at $400 \mathrm{ppm}$ and above. Very low hatchability $(19 \pm 1.20 \%$ and $0 \%)$ was observed at a 350 ppm concentration of ethanol and methanol extracts of Phyllanthus emblica, respectively against Anopheles stephensi. Almost 100\% hatchability was obtained in the control. In the case of ovicidal activity, exposure to freshly laid eggs was more effective than to the older eggs.

\section{Discussion and conclusions}

Many approaches have been developed to control the mosquito menace. One such approach to prevent mosquito-borne disease is by killing mosquito at the larval stage. The current mosquito control approach is based on synthetic insecticides. Even though they are effective, they created many problems, such as insecticide resistance (Liu et al., 2005), pollution, and toxic side effects on humans (Lixin, 2006). In the present study, OSLE showed higher larvicidal activities against mosquito probably due to the presence of active compounds such as eugenol and (E)-6-hydroxy-4,6-dimethyl-3-heptene-2-one (Kelm \& Nair, 1998). The mosquito larvicidal property of leaf and flower extracts of Ocimum sanctum L. against Aedes aegypti and Culex quinquefasciatus larvae has been previously reported (Anees, 2008). Mosquito breeding habitats vary from ponds, marshes, ditches, pools, drains, water containers and other similar water collections, and are often species-specific (Rozendaal, 1997). The increase in the mosquito vector population and the incidence of mosquito-borne diseases (e.g., malaria, dengue, and Chikungunya) is rising in India as a result of inadequate water supply systems and contamination. Storage of water, often from untreated water sources, and polluted water systems serve breeding sites of mosquitoes that transmit mosquito-borne pathogens, in addition to waterborne pathogens (e.g., cholera, dysentery and typhoid) (Vinod, 2011). In the present study, the treatment with coagulants at the breeding sites of mosquito had not only killed mosquito larvae but it had also water purifying properties. Biopesticide spray operations had been performed in the past (Murugan, 2006) for the control of vectors in the tsunami affected areas of India and the plant products such as neem and other herbal combinations showed biopesticidal potency killing mosquito larvae in the contaminated water. Larvicidal effect of neem (Azadirachta indica) oil cake was studied against mosquitoes. The oil cake showed good larvicidal activity against the mosquito species tested (Shanmugasundaram et al., 2008). Neem is derived from the neem tree Azadirachta indica A. Juss. (Meliaceae), and its primary insecticidal components are the tetranortriterpenoid, azadirachtin and other limonoids. The effect of neem limonoids azadirachtin, salannin, deacetylgedunin, gedunin, 17-hydroxyazadiradione and deacetylnimbin on insects was investigated by Senthil Nathan et al. (2006).

Coagulants of Ocimum sanctum were tested for the purifying properties at the laboratory by adding coagulants with waters from mosquito breeding sites and coagulants also had water purifying properties; treated water showed cleaning efficacy. Plant product nutrients (vitamin A and C, calcium, iron and zinc) and allelochemicals (Tannins, alkaloids, glycosides and saponins) not only removed solid contami- 
Table 4. Toxicity evaluation of ethanol extract of Phyllanthus emblica against the malarial vector Anopheles stephensi.

\begin{tabular}{|c|c|c|c|c|c|c|c|c|c|c|}
\hline \multirow[t]{2}{*}{$\begin{array}{l}\text { Larval } \\
\text { stages }\end{array}$} & \multicolumn{5}{|c|}{$\begin{array}{l}\% \text { of larval mortality } \\
\text { Concentration (ppm) }\end{array}$} & \multirow[t]{2}{*}{$\begin{array}{c}\mathrm{LC}_{50} \\
\left(\mathrm{LC}_{90}\right)\end{array}$} & \multirow[t]{2}{*}{$\begin{array}{l}\text { Regression } \\
\text { equation }\end{array}$} & \multicolumn{2}{|c|}{$\begin{array}{c}\text { 95\% Confidence } \\
\text { limit }\end{array}$} & \multirow{2}{*}{$\begin{array}{l}\text { Chi-square } \\
\text { value }\end{array}$} \\
\hline & 20 & 40 & 60 & 80 & 100 & & & $\begin{array}{c}\mathrm{LCL} \\
\mathrm{LC}_{50}\left(\mathrm{LC}_{90}\right)\end{array}$ & $\begin{array}{c}\mathrm{UCL} \\
\mathrm{LC}_{50}\left(\mathrm{LC}_{90}\right)\end{array}$ & \\
\hline I & $43 \pm 1.32^{\mathrm{a}}$ & $52 \pm 1.80^{b}$ & $68 \pm 2.59 c$ & $71 \pm 0.5^{\text {cd }}$ & $82 \pm 1.80^{\mathrm{d}}$ & $\begin{array}{c}33.08 \\
(128.48)\end{array}$ & $\begin{array}{l}Y=-0.44449 \\
+0.01343 \mathrm{X}\end{array}$ & $\begin{array}{c}18.26 \\
(110.01)\end{array}$ & $\begin{array}{c}42.76 \\
(162.10)\end{array}$ & 1.125 \\
\hline II & $36 \pm 0.70^{\mathrm{a}}$ & $43 \pm 1.22^{b}$ & $59 \pm 1.14^{\mathrm{c}}$ & $62 \pm 1.41^{\mathrm{cd}}$ & $78 \pm 0.79^{d}$ & $\begin{array}{c}48.85 \\
(142.98)\end{array}$ & $\begin{array}{l}Y=-0.66503 \\
+0.01361 X\end{array}$ & $\begin{array}{c}38.55 \\
(122.19)\end{array}$ & $\begin{array}{c}57.18 \\
(180.48)\end{array}$ & 1.793 \\
\hline III & $20 \pm 0.65^{\mathrm{a}}$ & $37 \pm 0.79^{b}$ & $48 \pm 1.58^{c}$ & $52 \pm 1.51^{\mathrm{cd}}$ & $70 \pm 0.79^{d}$ & $\begin{array}{c}68.28 \\
(151.79)\end{array}$ & $\begin{array}{l}Y=-1.04788 \\
+0.01535 \mathrm{X}\end{array}$ & $\begin{array}{c}60.85 \\
(131.41)\end{array}$ & $\begin{array}{c}76.82 \\
(186.42)\end{array}$ & 2.670 \\
\hline IV & $16 \pm 0.35^{a}$ & $23 \pm 0.79^{b}$ & $33 \pm 1.11^{\mathrm{c}}$ & $44 \pm 1.81^{\mathrm{d}}$ & $68 \pm 1.06 \mathrm{e}$ & $\begin{array}{c}81.26 \\
(153.33)\end{array}$ & $\begin{array}{l}Y=-1.44506 \\
+0.01778 X\end{array}$ & $\begin{array}{c}74.16 \\
(134.81)\end{array}$ & $\begin{array}{c}90.58 \\
(183.07)\end{array}$ & 2.728 \\
\hline Pupa & $12 \pm 1.59^{\mathrm{a}}$ & $21 \pm 0.65^{b}$ & $31 \pm 1.19 c$ & $40 \pm 1.98^{\mathrm{d}}$ & $64 \pm 1.06^{\mathrm{e}}$ & $\begin{array}{c}86.24 \\
(156.45)\end{array}$ & $\begin{array}{l}Y=-1.57407 \\
+0.01825 X\end{array}$ & $\begin{array}{c}78.85 \\
(137.64)\end{array}$ & $\begin{array}{c}96.30 \\
(186.67)\end{array}$ & 2.032 \\
\hline
\end{tabular}

Within a column means followed by the same letter(s) are not significantly different at 5\% level by Duncan Multiple Range Test. LC ${ }_{50}$, LC $\mathrm{g}_{9}$, lethal concentration; LCL, lower confidence limits; UCL, upper confidence limits.

Table 5. Toxicity evaluation of methanol extract of Phyllanthus emblica against the malarial vector Anopheles stephensi.

\begin{tabular}{|c|c|c|c|c|c|c|c|c|c|c|}
\hline \multirow[t]{2}{*}{$\begin{array}{l}\text { Larval } \\
\text { stages }\end{array}$} & \multicolumn{5}{|c|}{$\begin{array}{l}\% \text { of larval mortality } \\
\text { Concentration (ppm) }\end{array}$} & \multirow[t]{2}{*}{$\begin{array}{c}\mathrm{LC}_{50} \\
\left(\mathrm{LC}_{90}\right)\end{array}$} & \multirow[t]{2}{*}{$\begin{array}{l}\text { Regression } \\
\text { equation }\end{array}$} & \multicolumn{2}{|c|}{$\begin{array}{l}95 \% \text { Confidence } \\
\text { limit }\end{array}$} & \multirow{2}{*}{$\begin{array}{l}\text { Chi-square } \\
\text { value }\end{array}$} \\
\hline & 20 & 40 & 60 & 80 & 100 & & & $\begin{array}{c}\mathrm{LCL} \\
\mathrm{LC}_{50}\left(\mathrm{LC}_{90}\right)\end{array}$ & $\begin{array}{c}\text { UCL } \\
\mathrm{LC}_{50}\left(\mathrm{LC}_{90}\right)\end{array}$ & \\
\hline I & $49 \pm 0.70^{\mathrm{a}}$ & $65 \pm 0.79^{b}$ & $75 \pm 0.35^{c}$ & $87 \pm 0.79^{d}$ & $98 \pm 1.27 \mathrm{e}$ & $\begin{array}{c}23.44 \\
(82.15)\end{array}$ & $\begin{array}{l}Y=-0.51187 \\
+0.02183 \mathrm{X}\end{array}$ & $\begin{array}{c}12.98 \\
(74.12)\end{array}$ & $\begin{array}{c}30.87 \\
(93.77)\end{array}$ & 3.173 \\
\hline II & $40 \pm 0.54^{\mathrm{a}}$ & $58 \pm 0.79^{b}$ & $69 \pm 1.06^{\mathrm{c}}$ & $82 \pm 1.08^{d}$ & $97 \pm 1.29^{\mathrm{e}}$ & $\begin{array}{l}33.10 \\
(89.81)\end{array}$ & $\begin{array}{l}Y=-0.74820 \\
+0.02260 \mathrm{X}\end{array}$ & $\begin{array}{c}25.11 \\
(81.53)\end{array}$ & $\begin{array}{c}39.27 \\
(101.65)\end{array}$ & 4.043 \\
\hline III & $38 \pm 0.35^{\mathrm{a}}$ & $44 \pm 0.70^{\mathrm{ab}}$ & $61 \pm 1.22^{b}$ & $76 \pm 1.41^{\mathrm{c}}$ & $90 \pm 1.76^{\mathrm{d}}$ & $\begin{array}{c}42.13 \\
(107.52)\end{array}$ & $\begin{array}{l}Y=-0.82596 \\
+0.01960 X\end{array}$ & $\begin{array}{c}34.42 \\
(96.59)\end{array}$ & $\begin{array}{c}48.39 \\
(123.90)\end{array}$ & 2.881 \\
\hline IV & $29 \pm 0.74^{a}$ & $37 \pm 0.65^{b}$ & $53 \pm 1.51^{c}$ & $62 \pm 1.29^{\mathrm{d}}$ & $88 \pm 1.38 \mathrm{e}$ & $\begin{array}{c}54.19 \\
(119.26)\end{array}$ & $\begin{array}{l}Y=-1.06730 \\
+0.01969 \mathrm{X}\end{array}$ & $\begin{array}{c}36.01 \\
(95.48)\end{array}$ & $\begin{array}{c}69.28 \\
(187.81)\end{array}$ & 6.398 \\
\hline Pupa & $20 \pm 0.35^{\mathrm{a}}$ & $29 \pm 0.70^{b}$ & $48 \pm 0.93^{c}$ & $52 \pm 1.47^{\mathrm{cd}}$ & $85 \pm 1.88^{d}$ & $\begin{array}{c}64.28 \\
(124.56) \\
\end{array}$ & $\begin{array}{c}Y=-1.36664 \\
+0.02126 \mathrm{X}\end{array}$ & $\begin{array}{c}46.70 \\
(97.90) \\
\end{array}$ & $\begin{array}{c}85.52 \\
(216.27) \\
\end{array}$ & 9.100 \\
\hline
\end{tabular}

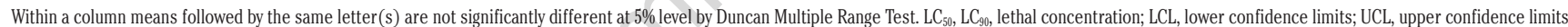

Table 6. Oviposition deterrence activity of ethanol and methanol extracts of Phyllanthus emblica against the malarial vector Anopheles stephensi.

\begin{tabular}{|c|c|c|c|c|c|c|c|c|}
\hline \multirow[t]{2}{*}{$\begin{array}{l}\text { Concentration } \\
\text { (ppm) }\end{array}$} & \multicolumn{4}{|c|}{$\begin{array}{l}\text { Ethanol } \\
\text { Number of eggs } \pm \text { S.E. }\end{array}$} & \multicolumn{4}{|c|}{$\begin{array}{c}\text { Methanol } \\
\text { Number of eggs } \pm \text { S.E. }\end{array}$} \\
\hline & Treatment & Control & ER\% & OAI & Treatment & Control & ER\% & OAI \\
\hline 500 & $49 \pm 1.15^{\mathrm{a}}$ & $456 \pm 1.50$ & 89.25 & -0.80 & $19 \pm 1.53^{\mathrm{a}}$ & $470 \pm 1.30$ & 95.95 & -0.92 \\
\hline 400 & $54 \pm 1.41^{\mathrm{b}}$ & $389 \pm 1.71$ & 86.11 & -0.75 & $23 \pm 1.22^{\mathrm{ab}}$ & $392 \pm 1.84$ & 94.13 & -0.88 \\
\hline 300 & $62 \pm 1.72^{\mathrm{c}}$ & $321 \pm 1.20$ & 80.68 & -0.67 & $37 \pm 1.84^{b}$ & $285 \pm 1.61$ & 87.01 & -0.77 \\
\hline 200 & $86 \pm 1.01^{\mathrm{d}}$ & $266 \pm 1.41$ & 67.66 & -0.51 & $48 \pm 1.73^{\mathrm{c}}$ & $220 \pm 1.42$ & 78.18 & -0.64 \\
\hline 100 & $98 \pm 1.52^{\mathrm{e}}$ & $210 \pm 1.47$ & 53.33 & -0.36 & $52 \pm 1.32^{\mathrm{cd}}$ & $160 \pm 1.32$ & 67.50 & -0.50 \\
\hline
\end{tabular}

Within a column means followed by the same letter(s) are not significantly different at $5 \%$ level by Duncan Multiple Range Test. S.E., standard error; ER, effective repellency; OAl, oviposition active index.

Table 7. Ovicidal activity of ethanol and methanol extracts of Phyllanthus emblica against eggs of Anopheles stephensi.

\begin{tabular}{|c|c|c|c|c|c|c|c|c|c|c|}
\hline \multirow[t]{2}{*}{ Treatment } & \multirow[t]{2}{*}{ Extract } & \multicolumn{9}{|c|}{$\begin{array}{l}\text { Percentage of egg hatchability } \pm \text { S.D. } \\
\text { Concentration of extract }(\mathrm{ppm})\end{array}$} \\
\hline & & 150 & 200 & 250 & 300 & 350 & 400 & 450 & 500 & Control \\
\hline Phyllanthus emblica & $\begin{array}{l}\text { Ethanol } \\
\text { Methanol }\end{array}$ & $\begin{array}{l}96 \pm 1.24^{\mathrm{e}} \\
74 \pm 2.17^{\mathrm{d}}\end{array}$ & $\begin{array}{l}71 \pm 2.43^{\mathrm{d}} \\
47 \pm 1.71^{\mathrm{c}}\end{array}$ & $\begin{array}{l}54 \pm 1.40^{\mathrm{c}} \\
22 \pm 2.10^{\mathrm{b}}\end{array}$ & $\begin{array}{l}30 \pm 2.49^{\mathrm{b}} \\
14 \pm 1.03^{\mathrm{a}}\end{array}$ & $\begin{array}{l}19 \pm 1.20^{\mathrm{a}} \\
\mathrm{NH}\end{array}$ & $\begin{array}{l}\mathrm{NH} \\
\mathrm{NH}\end{array}$ & $\begin{array}{l}\mathrm{NH} \\
\mathrm{NH}\end{array}$ & $\begin{array}{l}\mathrm{NH} \\
\mathrm{NH}\end{array}$ & $\begin{array}{l}100 \pm 0.00 \\
98 \pm 2.95\end{array}$ \\
\hline
\end{tabular}

Within a column means followed by the same letter(s) are not significantly different at 5\% level by Duncan Multiple Range Test. S.D., standard deviation; NH, no hatchability (100\% mortality). 
nants, but also greatly reduced amounts of harmful bacteria in the waste water. Earlier studies examined the antimicrobial property present in the Ocimum sanctum, and concluded that the component responsible was likely to be eugenol. This component has been demonstrated to have both antibacterial (Nakaruma et al., 1999) and antihelmintic activities (Pessoa et al., 2002). Nareshkumar et al. (2011) reported mosquitocidal and water purifying properties of different plant extracts (Cynodon dactylon, Aloe vera, Hemidesmus indicus and Coleus amboinicus) on various mosquito vectors (Anopheles stephensi, Culex quinquefasciatus and Aedes aegypti) at different water samples.

In the present study, we also sought to determine whether methanol and ethanol extracts from Phyllanthus emblica fruits could be used for mosquito control. We observed a functional response by all immature life stages of A. stephensi to ethanolic and methanolic extracts of Phyllanthus emblica fruits. This biological activity is attributed to the compounds present in fruits, including flavonoids, phenols, and steroids that together or independently result in morbidity and mortality in A. stephensi. Park et al. (2000) showed that the biological activity of the plant extracts might be due to the various compounds, including phenolics, terpenoids and alkaloids existing in plants. These compounds may jointly or independently contribute to produce larvicidal activity against mosquitoes. A piperidine alkaloid from Piper longum fruit was found to be active against mosquito larvae of $C x$. pipiens (Lee, 2000).

It was recognized that the fourth larval stage of mosquitoes was more tolerant to toxicant then early instars (Mulla, 1961; Rettich, 1976; Nareshkumar et al., 2012). Larval mortality may be due to the effect of chemicals like flavonoids, alkaloids, and terpenoids. The higher mortality of mosquito larvae was due to the combined action of plant compounds that might be acting on the midgut epithelium cells exerting their toxic effects on mosquito. Lethal $\mathrm{LC}_{50}$ observed in the present study is very low when compared to the earlier studies. The mangrove plant Rhizophora mucronata bark and pith extract showed toxicity with $\mathrm{LC}_{50}$ values of 157.4 and $168.3 \mathrm{ppm}$, respectively, against $A e$. aegypti larvae (Kabaru \& Gichia, 2001).

Exposure of $A$. stephensi larvae to sub-lethal doses of neem extracts in the laboratory, prolonged larval development, reduced pupal weight, caused high oviposition deterrence and high mortality (Wandscheer et al., 2004). Phyllanthus emblica $L$. was also effective in oviposition deterrence and ovicidal activities. Adult female A. stephensi avoided oviposition in Phyllanthus emblica-treated water, though some laid eggs, but these hatched in abnormal larvae. The ethanolic leaf extracts of Cassia obtusifolia at high concentration $\left(400 \mathrm{mg}^{*} \mathrm{l}-1\right)$ were responsible for $92.5 \%$ oviposition deterrence effect, while 300,200 and $100 \mathrm{mg}^{*} \mathrm{l}-1$ were responsible for $87.2 \%, 83.0 \%$, and $75.5 \%$ deterrence effect, respectively (Rajkumar \& Jebanesan, 2009). The leaf extract of Solanum trilobatum reduced egg laying by gravid females of Anopheles stephensi from 18\% to $99 \%$ compared with ethanol-treated controls at $0.01,0.025,0.05,0.075$, and $0.1 \%$ (Rajkumar \& Jebanesan, 2005). Methanol extract of Phyllanthus emblica showed more deterrence and egg mortality than the ethanol extract. The crude acetone extract of Cuscuta hyaline was an effective oviposition deterrent against Culex quinquefasciatus at a concentration of $80 \mathrm{ppm}$ (Mehra \& Hiradhar, 2002). It has been shown that the age of the embryos at the time of treatment plays a crucial role with regard to the effectiveness of the chitin synthesis inhibitor dimilin to Culex quinquefasciatus (Miura et al., 1976). The Ovicidal effect of Solenostemma argel was low; however, concentrations of $0.05 \%$ and 0.1 $\%$ exhibited significant effects $(\mathrm{P}<0.05)$, producing $65-75 \%$ and 62.9 $62.9 \%$, respectively, on the first and second day after treatment, the $0.1 \%$ concentration reduced egg hatch by $33.7 \%$, compared with control, and $100 \%$ mortality values were evident in concentrations as low as $0.025 \%$ at two days post-hatching against Culex pipiens (Al-Doghairi et al., 2004). The seed extract of Atriplex canescens showed complete ovicidal at $1000 \mathrm{ppm}$ concentration in eggs of Culex quinquefasciatus. The bioactive compound Azadirachtin isolated from Azadirachta indica showed complete Ovicidal activity in eggs of Culex tarsalis and Culex quinquefasciatus exposed to $10 \mathrm{ppm}$ concentration (Murugan et al., 1996; Ouda et al., 1998).

The phytochemical analysis of Phyllanthus emblica L. reveals the presence of alkaloids, tannins and saponins. These compounds are known to be biologically active. Tannins have important roles such as stable and potent antioxidants (Trease et al., 1978). Herbs that have tannins as their main component are astringent in nature and are used for treating intestinal disorders such as diarrhea and dysentery (Dharmananda, 2003). That of the largest group of chemicals produced by plants are the alkaloids and their amazing effect on humans has led to the development of powerful pain killer medications (Raffauf, 1996). Fruits are an important group of foodstuffs in the diet. These components of human diet are not adequately replaceable by any other products. Plant tissues are naturally rich in nutritive or therapeutically active products of plant secondary metabolism. The consumption of fruits has been inversely associated with morbidity and mortality from degenerative diseases (Aruoma, 1998; Özen, 2010) and is associated with low incidences and mortality rates of cancer and heart disease (Ames et al., 1993; Dragsted et al., 1993). It is not known which dietary constituents are responsible for this association, but antioxidants appear to play a major role in the protective effects of plant foods (Gey 1990; Barberousse et al., 2008; Patra \& Kumar, 2010). Fruit contains considerable amounts of active components such as polyphenols, flavonoids, tannins, vitamins A, B, C and E, and carotenoids which are considered potent scavengers of free radicals and reactive oxygen species (Rice-Evans et al., 1995).

The present results suggest that Ocimum sanctum can be used for mosquitocidal and water purifying purposes for promoting water sustainability in developing countries. Ocimum sanctum coagulum has an added advantage of having antimicrobial properties. Considering the fact that Ocimum sanctum coagulum can be locally produced, its use in water purification should be encouraged. This is likely to reduce the high cost of the current water treatment systems. Experiments on phytochemical screening of Phyllanthus emblica for their, larvicidal, pupicidal, ovipositiondeterrent and ovicidal activity have opened the possibility of further investigations on their efficiency, in view of the utilization of their higher biomass. However, the mechanism of action of the compounds from Phyllanthus emblica is still not clear. Studies on isolation, purification and the mechanism of action of individual compounds existing in the Phyllanthus emblica are needed and these are in progress.

\section{References}

ABBOTT W.S., 1925 - A method of computing the effectiveness of insecticides. - J. Econ. Entomol. 18: 265-267.

AL-DOGHAIRI M.A., AL-REHIAYANI S., OSMAN K.A., ELHAG E.A., 2004 Residual effects of some conventional and biorational pesticides on ladybird beetle, Adonia variegata goeze. - Pak. J. Biol. Sci. 7: 130133.

AMES B.M., SHIGENAGA M.K., HAGEN T.M., 1993 - Oxidants, antioxidants and the degenerative diseases of aging. - Proc. Natl. Acad. Sci. 90: 7915-7922.

ANEES A.M., 2008 - Larvicidal activity of Ocimum sanctum Linn (Labiate) against Aedes aegypti (L.) and Culex quinquefasciatus (Say). - J. Parasitol. Res. 103: 1451-1453.

ARUOMA 0.I., 1998 - Free radicals, oxidative stress, and antioxidants in human health and disease. - J. Am. Oil Chem. Soc. 75: 199-212.

BARBEROUSSE H., ROISEUX 0., ROBERT C., PAQUOT M., DEROANNE C., BLECKER C., 2008 - Analytical methodologies for quantification of ferulic acid and its oligomers. - J. Sci. Food Agric. 88: 1494-1511. 
BUTANI D.K., 1982 - Insect pests of Tulsi (Ocimum sanctum Linnaeus) and their controls. - Pesticides. 16: 11-12.

CALIXTO J.B., ANTOS A.R.S., FILHO V.C., TUNES R.A., 1998 - A review of the plants of the genus phyllanthus : their chemistry, pharmacology, and therapeutic potential. - J. Med. Biol. 31: 225-258.

CHENNIAPPAN K., KADARKARAI M., 2008 - Oviposition deterrent, ovicidal and gravid mortality effects of ethanolic extract of Andrographis paniculata Nees against the malarial vector Anopheles stephensi Liston (Diptera: Culicidae). - Entomol. Res. 38: 119-125.

CLESCERL LEONORE S., GREENBERG ARNOLD E., EATON ANDREW D., 2005. - Standard methods for the examination of water and wastewater (20th ed.). American Public Health Association, Washington, DC.

CURTIS C.F., 1994 - The case for malaria control by genetic manipulation of its vectors. -Parasitol. Today. 10: 371-374.

DHARMANANDA S., 2003 - Gallnuts and the uses of Tannins in Chinese medicine. - In; Proceedings of Institutes for Traditional Medicine, Portland, Oregon. Available from: http://www.itmonline.org/arts /gallnuts.htm

DRAGSTED L.O., STRUBE M., LARSEN J.C., 1993 - Cancer-protective factors in fruits and vegetables: biochemical and biological background. - Pharmacol. Toxicol. 72: 116-135.

GEY K.F., 1990 - The antioxidant hypothesis of cardiovascular-disease epidemiology and mechanisms. - Biochem. Soc. Trans. 18: 10411045.

GRAINAGE M., AHMED H., 1988 - Handbook of plants and pest control properties. John Wiley and Sons, New York, NY.

HARDSTONE C.M., LAZZARO P.B., SCOTT G.J., 2009 - The effect of three environmental conditions on the fitness of cytochrome P450.monooxygenase-mediated permethrin resistance in Culex pipiens. - BMC Evol. Biol. 9: 42.

KABARU J.M., GICHIA L., 2001 - Insecticidal activity of extracts derived from different parts of the mangrove tree Rhizophora mucronata (Rhizophoraceae) Lam. against the arthropods. Afr. J. Sci. Technol. 2: 44-49.

PATRA K.C., KUMAR K.J., 2010 - Establishing correlation of therapeutic activity of a siddha formulation with its antioxidant activity- a comparative study. - Int. J. Pharma Bio Sci. 1: 1-8.

KELM M.A., NAIR M.G., 1998 - Mosquitocidal compounds and a triglyceride, 1, 3-dilinoleneoyl-2-palmitin, from Ocimum sanctum. - J. Agric. Food Chem. 46: 3092-309.

KHOPDE S.M., PRIYADARSHINI K.I., GUHA S.N., SATAV J.G., VENKATESAN P., RAO M.N.A., 2000 - Inhibition of radiationinduced lipid peroxidation by tetrahydrocurcumin: Possible mechanism by pulse radiolysis. - Biosci. Biotechnol. Biochem. 64: 503-509.

KIRTIKAR K.R., BASU B.D., 1975 - Indian medicinal plant. Vol 3, $2^{\text {nd }}$ ed. - International Book Distributor, Dehra Dun: 2327-2328.

KOKATE C.K., PUROHITH A.P., GOKHALE S.B., 1990 - Pharmacognosy. $1^{\text {st }}$ ed. - Nirali Prakashan, Pune: 120.

KRAMER W.L., MULLA S., 1979 - Oviposition attractants and repellents of mosquitoes: oviposition responses of Culex mosquitoes to organic infusions. - Environ. Entomol. 8: 1111-1117.

LEE S.E., 2000 - Mosquito larvicidal activity of pipernonaline, a piperidine alkaloid derived from long pepper, Piper longum. - J. Am. Mosq. Control Assoc. 16: 245-7.

LIU H., XU Q., ZHANG L., LIU N., 2005 - Chlorpyrifos resistance in Mosquito Culex aegypti and Culex pipiens pallens. - J. Med. Ent. 42: 815-820.

LIXIN S., HUIQUIN D., CHONGXIA G., JIN Q., JING S., LEI M., et al., 2006 Larvicidal activity of extracts of Ginko biloba Exocarp for three different strains of Culex pipiens pallens. - J. Med. Ent. 43: 258-261.
MEHRA B.K., HIRADHAR P.K., 2002 - Cuscuta hyalina Roth., an insect development inhibitor against common house mosquito Culex quinquefasciatus Say. - J. Environ. Biol. 23: 335-339.

MERRILY K., WINSTON D., 2007 - Winston \& Kuhn's herbal therapy \& supplements: a scientific and traditional approach. - Lippincott Williams \& Wilkins, Philadelphia, PA: 260.

MIURA T., SCHAFER C.H., TAKAHASHI R.M., MULLIGAN F.S., 1976 Effects of insect growth inhibitor, dimilin on hatching of mosquito eggs. - J. Econ. Ent. 69: 655-658.

MULLA M.S., 1961 - Suseptibility of various larval instars of Culex pipens, quinqufasciatus say to insecticides. - Mosq. New. 21: 320323.

MURUGAN K., JAHANMOHINI P., BABU R., 1996 - Effect of neem kernel extract and neem oil on Nutritive and Reproductive Physiology of Heliothis armigera Hub. In: Singh R.P., Chari M.S., Raheja A.K., Kravs W., (eds.). Neem and environment, vol. 1. - Oxford and IBH Co., Pvt. Ltd. Delhi: 321-334.

MURUGAN K., 2006 - Tsunami relief work - Biopesticide spray operations - A case study. In: Nadim F., Pöttler R., Einstein H., Klapperich H., Kramer S., (eds.). Geohazards. - ECI Symposium Series, Volume P7. Available from: http://services.bepress.com/eci/geohaz$\operatorname{ards} / 39$

MURUGAN K., VAHITHA R., BARUAH I., DAS S.C., 2003 - Integration of botanicals and microbial pesticides for the control of filarialvector, Culex quinquefasciatus-. Ann. Med. Entomol. 12: 11-23.

NAKARUMA C.V., NAKARUMA T.U., BANDO E., MELO A.F.N., CORTEZ D.A.G., DIAZ FILHO B.P., 1999 - Antibacterial activity of Ocimum gratissimum L. essential Oil. - Mem. Inst. Oswardo Cruz. 94: 675-578.

NARESHKUMAR A., MURUGAN K., REJEETH C., MADHIYAZHAGAN P., DONALD R. BARNARD, 2012 - Green synthesis of silver nanoparticles for the control of mosquito vectors of Malaria, Filariasis, and Dengue. - Vector-Borne Zoonot. 12: 262-268.

NARESHKUMAR A., MURUGAN K., MADHIYAZHAGAN P., KOVENDAN K., PRASANNAKUMAR K., THANGAMANI S., et al., 2011 - Mosquitocidal and water purification properties of Cynodon dactylon, Aloe vera, Hemidesmus indicus and Coleus amboinicus leaf extracts against the mosquito vectors. - Parasitol Res. 110: 1435-1443.

OUDA N.A.A., AL-CHALABI B.B.M., AL-CHARCHAFCHI F.F.M.R., MOHSEN Z.Z.H., 1998 - Extract of Atriplex canescens against Culex quinquefasciatus. - Pharm. Biol. 36: 69-71.

PARK I.K., LEE H.S., LEE S.G., PARK J.D., YOUNG-JOON A.H.N., 2000 Antifeeding activity of isoquinoline alkaloids identified in Coptis japonica roots against Hyphantria cunea (Lepidoptera: Arctiidae) and Agelastica coerulea (Coleoptera: Galerucinae). - J. Econ. Entomol. 93: 331-335.

PESSOA L.M., MORAIS S.M., BEVILAQUA C.M.L., LUCIANO J.H.S., 2002 - Antihelmintic activity of essential oil of Ocimum gratissimum Linn. and Eugenol against Haemonchus contortus. - Vet. Parasitol. 109: 59-63.

RAFFAUF R.F., 1996 - Plant alkaloids: a guide to their discovery and distribution. - Hawkworth Press, Inc., New York, NY.

RAJKUMAR S., JEBANESAN A., 2005 - Oviposition deterrent and skin repellent activities of Solanum trilobatum leaf extract against the malarial vector Anopheles stephensi. - J. Insect. Sci. 5: 15.

RAJKUMAR S., JEBANESAN A., 2009 - Larvicidal and oviposition activity of Cassia obtusifolia Linn (Family: Leguminosae) leaf extract against malarial vector, Anopheles stephensi Liston (Diptera: Culicidae). - Parasitol. Res. 104: 337-340.

RETTICH F., 1976 - Changes in susceptibility to temphos primiphosmethyl fenitrothion and bromophos during preimaginal development of mosquitoes. - Acta. Ent. Bohemoslov. 73: 382-387.

RICE-EVANS C.A., MILLER N.J., BOLWELL P.G., BRAMLEY P.M., PRIDHAM J.B., 1995 - The relative antioxidant activities of plant-derived polyphenolic flavonoids. - Free Radical Res. 22: 375-383. 
ROZENDAAL J.A., 1997 - Mosquitoes and other biting Diptera. In: Vector control - methods for use by individuals and communities. World Health Organization, Geneva: 7-177. Available from: http://www.who.int/whopes/resources/vector_rozendaal/en/

SCHWARZ D., 2000 - Water clarification using Moringa oleifera. Technical Information Wle,

Gate Information Service, Eschborn, Germany. - Available form: http:/www.gtz.de/gate/gateid.afp Accessed: 31 ${ }^{\text {st }}$ October 2007.

SENTHIL NATHAN S., KALAIVANI K., CHUNG P.G., MURUGAN K., 2006 - Effect of neem limonoids on lactate dehydrogenase (LDH) of the rice leaffolder, Cnaphalocrocis medinalis (Guene'e) (Insecta: Lepidoptera: Pyralidae). - Chemosphere. 62: 1388-1393.

SHANMUGASUNDARAM R., JEYALAKSHMI T., DUTT M.S., MURTHY P.B., 2008 - Larvicidal activity of neem and karanja oil cakes against mosquito vectors, Culex quinquefasciatus (say), Aedes aegypti (L.) and Anopheles stephensi (L.). - J. Environ. Biol. 29: 43-5.

SU T., MULLA M.S., 1998 - Ovicidal activity of neem products
(Azadirachtin) against Culex tarsalis and Culex quinquefasciatus (Diptera: Culicidae). - J. Am. Mosq. Cont. Assoc. 14: 204-209.

ÖZEN T., 2010 - Antioxidant activity of wild edible plants in the Black Sea Region of Turkey. - Grasas Y Aceites. 61, 86-94.

TREASE G.E., EVANS W.C., 1978 - A text book of pharmacognosy, 11th ed. - Bailliere Tidall, London: 530.

VINOD S., 2011 - Deforestation and water pollution impact on mosquitoes related epidemic diseases in nanded region. - Biosci. Discov. 2: 309-316.

WANDSCHEER C.B., DUQUE J.E., FUKUYAMA Y., WOHLKE J.L., FONTANA J.D., 2004 - Larvicidal action of ethanolic extracts from fruit endocarps of Melia azedarach and Azadirachta indica against the dengue mosquito Aedes aegypti. - Toxicon. 44: 829-835.

WHO (WORLD HEALTH ORGANIZATION)/UNICEF (Joint Monitoring Programme for Water Supply and Sanitation), 2005 - Water for life: making it happen. World Health Organization, Geneva. Available from: http://www.who.int/water_sanitation_health/monitoring/jmp 2005/en 